\title{
Persepsi Guru tentang Social Distancing pada Pendidikan AUD Era New Normal
}

\author{
Masganti Sit. ${ }^{\bowtie}$, Muhammad Shaleh Assingkily² \\ Pendidikan Islam Anak Usia Dini, Universitas Islam Negeri, Sumatera Utara Medan \\ Pendidikan Guru Madrasah Ibtidaiyah, Universitas Islam Negeri, Sumatera Utara Medan \\ DOI: $10.31004 /$ obsesi.v5i2.756
}

\begin{abstract}
Abstrak
Social Distancing dan pembelajaran jarak jauh menjadi hal familiar sejak pandemi covid-19. Begitupun, sistem pembelajaran era new normal mulai dikondisikan dengan mengikut kebijakan pada tiap-tiap daerah, terutama bagi anak usia dini. Tulisan ini bertujuan menganalisa persepsi guru tentang social distancing dan pola pembelajaran yang diterapkan pada PAUD era new normal di RA/TK Kab. Aceh Tenggara. Penelitian kualitatif dengan metode field research dipilih dalam tulisan ini untuk mengungkap data dengan teknik pengumpulan data wawancara mendalam, observasi partisipan, dan studi dokumen. Berdasarkan penelitian ini, ditemukan bahwa (1) guru memandang bahwa social distancing adalah pembatasan jarak sosial sementara karena pandemi, untuk itu pendidikan pada AUD di RA/TK Kab. Aceh Tenggara mengalami 3 kali transisi pola, mulai dari via WhatsApp Group (WAG), belajar kunjungan dan sistem bergilir; dan (2) platform social distancing pada PAUD di era new normal meliputi aspek pembelajaran, penugasan dan penilaian.
\end{abstract}

Kata Kunci: new normal; paud; persepsi guru; social distancing.

\begin{abstract}
Social Distancing and distance learning have become familiar things since the Covid-19 pandemic. Likewise, the new normal era learning system began to be conditioned by following policies in each region, especially for early childhood. This paper aims to analyze teachers' perceptions about social distancing and learning patterns applied to the new normal era PAUD in RA / TK Kab. Southeast Aceh. Qualitative research using the field research method was chosen in this paper to reveal data using in-depth interview data collection techniques, participant observation, and document study. Based on this research, it is found that (1) the teacher views that social distancing is a temporary limitation of social distance due to the pandemic, therefore education at AUD in RA / TK Kab. Aceh Tenggara experienced 3 times of pattern transition, starting from via WhatsApp Group (WAG), learning visits and a rotating system; and (2) the social distancing platform in PAUD in the new normal era includes aspects of learning, assignments and assessments.
\end{abstract}

Keywords: new normal; paud; teacher perception; social distancing.

Copyright (c) 2020 Masganti Sit, Muhammad Shaleh Assingkily

$\triangle$ Corresponding author : Masganti Sit.

Email Address: masganti@uinsu.ac.id (Medan-Sumatera Utara, Indonesia)

Received 9 September 2020, Accepted 24 September 2020, Published 25 September 2020 


\section{PENDAHULUAN}

Social distancing menjadi dimensi baru dalam dunia pendidikan (Syarifudin, 2020; Pramana, 2020). Interaksi dan komunikasi yang menjadi ciri khas pembelajaran serta membina kedekatan emosional antarkomponen pendidikan, menjadi "terhambat" dengan kebijakan ini (Herdiana, 2020). Social distancing telah membawa dampak positif dan negatif pada dunia pendidikan dan aspek kehidupan lainnya dalam situasi pandemi covid-19. Di satu sisi Social distancing menyebabkan pembelajaran saat ini untuk sementara waktu dilaksanakan melalui sistem daring (daring). Sistem pembelajaran menjadikan ini menyebabkan anak minim perhatian dan terbatas memperoleh informasi dari orang lain. Namun di sisi lain, social distancing diyakini memberi rasa aman bagi orang tua, guru, atau anggota masyarakat lainnya dari terpapar wabah virus covid-19 (Rohmadani, 2020; Indrawati, 2020).

Pengaturan pola pembelajaran yang menerapkan social distancing.merupakan upaya untuk memberikan kesempatan kepada peserta didik, termasuk anak usia dini untuk tetap belajar, agar dampak covid-19 tidak berakibat pada "musnahnya" satu generasi akibat minim pengetahuan atau dikenal dengan istilah lost generation (Crul, 2020). Oleh sebab itu, pola pembelajaran diatur dan dikembangkan secara insidental sesuai dengan anjuran social distancing. Hal ini berimplikasi pada fenomena pola pembelajaran yang diterapkan oleh lembaga pendidikan, sesuai dengan situasi dan kondisi (Sadikin \& Hamidah, 2020:214-224). Di antaranya, menerapkan pembelajaran pola bergilir, pola masuk sehari off sehari, dan pola belajar kunjungan. Hal ini dijadikan sebagai alternatif pembelajaran di era covid-19 dan masa penetapan social distancing (Indrayana \& Sadikin, 2020:46-55).

Berkaitan dengan penerapan social distancing dalam pendidikan, guru sebagai garda terdepan dalam memastikan berlangsungnya proses pembelajaran bagi anak didik memiliki pandangan berbeda mengenai penerapan kebijakan social distancing (Wijoyo \& Indrawan, 2020). Hal ini tercermin dari bagaimana guru melaksanakan pembelajaran di masa pandemi covid-19 (Wulandari, 2020). Ditambah lagi, keragaman informasi yang diterima serta diperoleh guru dari media cetak, media sosial, informasi dari teman ke teman, dan media literatur lainnya (Latip, 2020; Permatasari, et.al., 2020). Di satu sisi guru atau pendidik pada satuan pendidikan jenjang anak usia dini, baik PAUD, RA maupun TK sederajat, khawatir anak tidak memperoleh pendidikan (pembelajaran) di masa pandemi covid-19, namun di sisi lain dikhawatirkan pula anak mudah terpapar virus corona tersebut. Paradoksal yang muncul di kalangan masyarakat mengenai pendidikan anak usia dini pada prinsipnya didasari kegelisahan terhadap generasi penerus estafet kehidupan.

Menyikapi hal ini, berbagai platform pembelajaran dilaksanakan oleh guru di setiap daerah sesuai dengan kebijakan nasional dan peraturan daerah setempat. Kutacane Kabupaten Aceh Tenggara, sebagai salah satu daerah yang masih tergolong aman (zona hijau) oleh pemerintah, menginisiasi tetap berlangsungnya proses pembelajaran bagi anak. Berbagai kebijakan pun turut ditetapkan oleh pihak yayasan dan internal lembaga. Hal ini sebagai upaya memastikan berlangsungnya proses pembelajaran bagi anak usia dini. Berbagai macam model dan bentuk pembelajaran pun diterapkan sesuai dengan kesepakatan internal pihak PAUD/TK/RA (Wijoyo \& Indrawan, 2020; Marbun, 2020:129-142). Upaya ini diselaraskan dengan persepsi para guru tentang social distancing, dan berimplikasi pada pola pembelajaran yang dilaksanakan (Rahmawati \& Putri, 2020).

Sejatinya, kajian mengenai pola pembelajaran di era covid-19 dan persepsi mengenai pola pembelajaran di era covid-19 telah diteliti oleh sejumlah orang. Di antaranya membahas kajian tersebut dari aspek pola belajar kunjungan dalam pendidikan non formal (Juwita, 2020), pola belajar dan bekerja dari rumah (WFH) (Mungkasa, 2020:126-150), pola belajar online via Google Classroom (Sutrisno, 2020), persepsi pendidik atas dampak covid-19 terhadap pembelajaran (Satrianingrum \& Prasetyo, 2020; Firman, 2020), pola pembelajaran online berbasis proyek (Arizona, et.al., 2020), persepsi peserta didik terhadap pembelajaran jarak jauh (e-learning) (Megawanti, et.al., 2020; Zhafira, et.al., 2020; Yuniarti \& Hartati, 2020; Riadi, et.al., 2020), persepsi orang tua tentang pembelajaran di rumah era covid-19 (Sabiq, 2020:1-7) dan 
DOI: 10.31004/obsesi.v5i2.756

kesiapan bermain bersama anak (Sari, et.al., 2020), serta persepsi guru terhadap pembelajaran menggunakan gawai (Wibowo, 2020).

Berdasarkan literature review di atas, diketahui bahwa terdapat "ruang kosong" analisis social distancing dari aspek persepsi guru di era new normal. Dengan demikian, dibutuhkan kajian lebih lanjut dan mendalam mengenai hal ini, yang terangkum dalam judul penelitian, "Persepsi Guru tentang Social Distancing pada PAUD di Era New Normal". Melalui penelitian ini, diharapkan para guru semakin objektif memandang social distancing dan solusinya terhadap pendidikan anak usia dini. Lebih lanjut, guru dapat mengantisipasi permasalahan serupa (covid-19) dengan terus memastikan pembelajaran dan pendidikan nilai tetap diberikan kepada anak. Bahkan, hasil ini dapat menjadi bentuk rekomendasi kepada stakeholder pendidikan anak usia dini untuk menjadi prototipe dalam merumuskan polarisasi pembelajaran yang tepat diberikan kepada anak usia dini sesuai anjuran social distancing di tengah masa pandemi covid-19.

\section{METODOLOGI}

Penelitian ini menggunakan pendekatan studi kasus kualitatif. Yin (2009: 25) menginformasikan bahwa penelitian studi kasus cocok digunakan untuk penelitian yang bertujuan melakukan eksplorasi pada hal-hal yang bersifat kontemporer. Oleh sebab itu, studi kasus dipilih peneliti, sebab penelitian ini bertujuan untuk mengeksplorasi persepsi guru tentang social distancing pada PAUD di era new normal merupakan hal yang bersifat kontemporer pada anak usia prasekolah. Penelitian ini dilakukan pada bulan Juni s/d Agustus 2020.

Berikut ditampilkan skema metodologi penelitian dalam bagan di bawah ini:

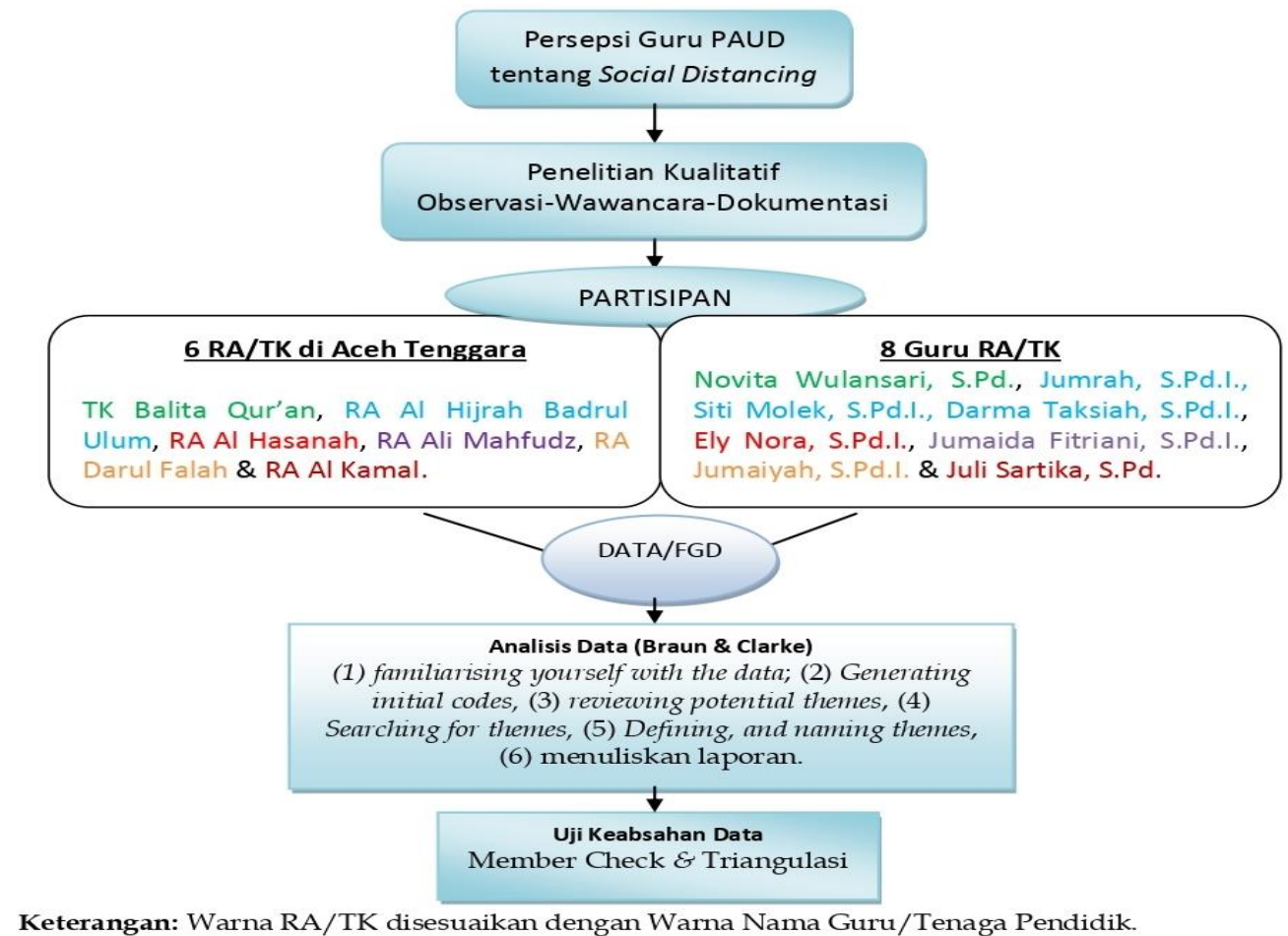

Skema 1. Bagan Metodologi Penelitian

Partisipan penelitian ini adalah 8 (delapan) guru yang mengajar di 6 (enam) RA/TK daerah Kutacane Aceh Tenggara yakni, Novita Wulansari, S.Pd. (dari TK Balita Qur'an), Jumrah, S.Pd.I., Siti Molek, S.Pd.I., dan Darma Taksiah, S.Pd.I. (dari RA Al Hijrah Badrul Ulum), Ely Nora, S.Pd.I. (RA Al Hasanah), Jumaida Fitriani, S.Pd.I. (RA Ali Mahfudz), Jumaiyah, S.Pd.I. (RA Darul Falah) dan Juli Sartika, S.Pd. (RA Al Kamal). Penentuan 
partisipan dilakukan memilih partisipan yang sesuai dengan demografi penelitian dan menyatakan bersedia memberikan data yang diperlukan dalam penelitian ini.

Pengumpulan data dilakukan dengan wawancara mendalam secara individual. Wawancara menggunakan telepon untuk mematuhi kepatuhan terhadap social distancing. Seidman (2006) menginformasikan bahwa wawancara telepon dapat digunakan untuk mengungkapkan apa yang dirasakan atau pikirkan oleh partsipan tentang fenomena yang diteliti. Panduan wawancara dikirimkan melalui pesan wash app ke partisipan seminggu sebelum wawancara dilakukan. Jadwal wawancara dilakukan dengan kesepakatan antara peneliti dan partisipan (Creswell, 2009). Wawancara dilakukan mendalam direkam dengan durasi wawancara antara 15-30 menit per orang. Wawancara dilakukan dengan pertanyaan terbuka sehingga partisipan dapat menggunakan bahasa sendiri untuk mengungkapkan halhal yang belum tersampaikan dalam FGD (Leavy, 2017: 139). Wawancara mendalam dilakukan sendiri oleh peneliti dan dibantu dengan tenaga teknis untuk melakukan rekaman dan membuat transkrip wawancara.

Transkrip FGD dan wawancara mendalam diolah dengan menggunakan analisis tematik dari Braun dan Clarke. Braun \& Clarke (2012) menawarkan 6 (enam) langkah analisis tematik. Pertama familiarising yourself with the data, yaitu peneliti membaca berulang-ulang transkrip FGD dan wawancara untuk mengungkapkan kekayaan informasi dari data. Kedua dan ketiga Generating initial codes, pada tahap ini peneliti melakukan pengkodean data secara manual untuk menemukan tema yang potensial. Ketiga, keempat, dan kelima reviewing potential themes, Searching for themes, Defining, and naming themes, dilakukan dengan meninjau tema-tema yang potensial, mencari, mendefinisikan, dan menamai tema dengan cara membaca berulang-ulang dan memutuskan tema utama yang muncul dari data. Keenam, menuliskan laporan.

Penjaminan validitas data penelitian dilakukan dengan member check dan triangulasi. Member check dilakukan dengan memberikan kesempatan kepada terwawancara untuk mengomentari hasil penelitian dalam bentuk draft artikel (Creswell, 2009: 191). Triangulasi dilakukan dengan membandingkan hasil wawancara antara satu partisipan dengan yang lainnya pada tema yang sama (Creswell, 2009: 191).

\section{HASIL DAN PEMBAHASAN}

Social distancing secara sederhana diartikan dengan "jarak sosial" (Courtemanche, et.al., 2020). Hal ini diterapkan sebagai upaya pemutusan rantai penyebaran virus covid-19 di Indonesia (Nurhalimah, 2020). Pembatasan sosial yang dilakukan ini telah berdampak pada bidang pendidikan (Abidah, et.al., 2020:38-49). Bahkan, pendidikan di tingkat pendidikan prasekolah terjadi "jeda" pembelajaran tatap muka untuk sementara waktu, sebab dikhawatirkan anak-anak terpapar virus (Tabi'in, 2020; Mushlih, et.al., 2020). Senada dengan ini, Novita salah seorang pengajar TK menuturkan:

"menurut saya, Social Distancing itu adalah pembatasan sosial atau jaga jarak antara satu dengan yang lainnya. Makanya, kita dengan orang lain termasuk anak murid di TK pun harus dibatasi, baik jarak temu, intensitas waktu bertemu, agar anak tetap aman." (Hasil Wawancara dengan Novita Wulansari, S.Pd., Guru TK Balita Quran)

Pembatasan sosial yang ada, sejatinya merupakan "niat baik" pemerintah dalam melindungi masyarakat (Siagian, 2020). Akan tetapi, hak belajar anak tereduksi, sehingga dikhawatirkan terjadi implikasi negatif pasca virus covid-19 yakni lost generation (Crul, 2017). Bahkan, target mencapai anak bangsa "emas" di 1 abad Indonesia (2025) terancam gagal (Ulum \& Pamungkas, 2020). Akibat anak-anak di usia dini (prasekolah) tidak memperoleh pendidikan yang mumpuni sebagai bekal kehidupan dan menciptakan SDM unggul (Rohayani, 2020).

Menyikapi penerapan kebijakan social distancing, berbagai pola pembelajaran pun diterapkan oleh lembaga pendidikan (Gunawan, et.al., 2020:61-70). Seperti halnya 6 (enam) 
DOI: 10.31004 /obsesi.v5i2.756

RA/TK Kabupaten Aceh Tenggara (yakni TK Balita Quran, RA Al Hasanah, RA Ali Mahfudz, RA Darul Falah, RA Al Kamal, dan RA Al Hijrah Badrul Ulum) yang menerapkan beberapa pola pembelajaran didasari perubahan kondisi dan kesepakatan pihak internal lembaga. Adapun pola pembelajaran yang diterapkan oleh pihak RA/TK secara berurutan yakni (1) pembelajaran via WhatsApp Group (WAG), (2) pola pembelajaran kunjungan dan (3) pola pembelajaran bergilir. Berikut penjelasan lebih lanjut.

\section{Pola Pembelajaran via WhatsApp Group}

Pembelajaran via WhatsApp Group (WAG) telah dimanfaatkan oleh praktisi pendidikan sebelum situasi pandemi dan penerapan kebijakan social distancing (Ellanur, 2017:1-14). Begitupun, pola pembelajaran ini secara umum dipandang efektif digunakan pada masa awal pandemi dan tidak bertentangan dengan instruksi social distancing (Mauly, 2020). RA/TK tersebut, pada awal penetapan kebijakan social distancing telah memanfaatkan WAG sebagai sarana pembelajaran. Hal ini dipandang aman karena secara online dan siswa tetap memperoleh kebutuhan pendidikan. Hal ini seperti yang disampaikan Jumaiyah, salah seorang pengajar di RA, berikut kutipan wawancaranya:

"di sekolah, kita awalnya mengajar hanya lewat Video/Daring. Setiap hari kita buat video lalu dikirim ke grup WA. Karena, dengan WA kita belajarnya aman, terlebih lagi sekarang kan udah keluar aturan social distancing, jadi via WA cocok kita gunakan." (Hasil Wawancara dengan Jumaiyah, S.Pd.I., Guru RA Al Falah)

Senada dengan di atas, Juli menuturkan:

"selama pandemi setelah ada edaran, pihak sekolah menetapkan pembelajaran online Bu. Ini kami buat supaya anak-anak aman di rumah, guru di rumah, tapi pembelajaran tetap berjalan. Namanya juga kita mematuhi aturan dan edaran dari Bupati Bu." (Hasil Wawancara dengan Juli Sartika, S.Pd., Guru RA Al Kamal)

Lebih lanjut, Novita mengungkapkan bahwa:

"Pembelajaran pake WAG ini bagus sekali diterapkan oleh pihak sekolah Bu, karena pastinya anak-anak tetap belajar. Apalagi sekarang kan sedang masanya social distancing, jadi kita ikut prosedur kesehatan tu Bu, istilahnya jaga jarak semester gitu Bu. Kalau pake WAG bukan lagi semester Bu, udah jauh kali pun." (Hasil Wawancara dengan Novita Wulansari, S.Pd., Guru TK Balita Quran)

Kutipan di atas mengkonfirmasi bahwa pemanfaatan WAG dapat membantu pendidik untuk tetap menjalankan tugasnya memberi pengajaran pada anak (Yensy, 2020). Menurut Perdana (2015: 279-297), setiap anak Indonesia berhak mendapat akses pendidikan, sebab bangsa Indonesia berkewajiban menjamin hak pendidikan tersebut. Lebih lanjut, akses tersebut menunjukkan hak merdeka belajar bagi anak (Kurniawan, 2020; Mustaghfiroh, 2020:141-147; Asfiati \& Mahdi, 2020). Ini juga merupakan bagian kesiapan mental para praktisi pendidikan di Indonesia dalam menghadapi situasi darurat dengan solutif dan inovatif.

Meskipun begitu, pembelajaran daring dengan WAG bagi siswa RA/TK juga tidak luput dari kelemahan sebagai alternatif proses pembelajaran (Astini, 2020:241-255). Hal ini disebabkan dengan keterbatasan akses anak menggunakan internet (Ulinnuha, 2013), rendahnya pengawasan dan fokus perhatian belajar anak dari orang tua (Tarma \& Hasanah, 2017), bahkan juga berimbas pada aspek ekonomi untuk memenuhi kuota internet orang tua (Dewi, 2020:55-61; Cahyati \& Kusumah, 2020). Sebagaimana disampaikan Jumaida Fitriani berikut ini:

“... dengan adanya grup WA, kami sebagai guru sangat merasa terbantu. Tapi, kalau dilihat-lihat selama belajar dengan Daring tidak efektif jugak, karena hanya beberapa wali murid yang bisa respon di grup WA sedangkan yang lainnya alasan tidak ada paket atau sibuk bekerja sehingga tidak sempat memvideokan anak." (Hasil Wawancara dengan Jumaida Fitriani, S.Pd.I., Guru RA Ali Mahfudz)

Kesulitan orang tua siswa terlibat aktif dalam pembelajaran daring disebabkan dampak covid-19 terhadap perekonomian masyarakat (Hanoatubun, 2020:146-153). Sementara di sisi lain anak berhak memperoleh pengajaran untuk mendukung proses 
perkembangan (Ikhsan, et.al., 2020). Atas dasar permasalahan ini, pihak TK melaksanakan rapat untuk menetapkan proses pembelajaran yang akan diterapkan sebagai pengganti WAG. Novita menginformasikan penggunaan WAG telah berlangsung selama 2 (dua) bulan penuh sejak awal bulan Mei hingga Juli. Dengan demikian, praktik pola pembelajaran WAG dapat dijadikan alternatif pembelajaran di tengah situasi darurat, meskipun masih terdapat kelemahan dan ketidakefektifan pembelajaran sepenuhnya berbasis WAG.

\section{Pola Pembelajaran Kunjungan}

Pembelajaran kunjungan merupakan salah satu pola yang diterapkan oleh pihak RA/TK (sejumlah 6 RA/TK yang diteliti) di Kabupaten Aceh Tenggara. Hal ini diawali atas dasar ketidakefektifan penggunaan WAG secara menyeluruh (Naserly, 2020:155-165). Ini juga merupakan hasil rapat yang ditetapkan oleh pihak pimpinan RA/TK atas konsensus para guru dan tenaga kependidikan di keenam RA/TK tersebut. Hal ini sebagaimana yang disampaikan oleh Darma berikut ini:

“... pake grup WA sangat membantu guru dalam mengajari anak, tapi kurang efektif karena orang tua banyak yang sudah mulai mengeluh harus kirim video, padahal ini kan mengikuti aturan social distancing juga Bu. Sebab itu, pimpinan RA mengundang kami untuk rapat, setelah itu lalu dari pihak sekolah memutuskan untuk Luring mengajar ke rumah-rumah wali murid, setiap kelas nanti akan belajar ke satu rumah wali murid." (Hasil Wawancara dengan Darma Taksiah, S.Pd.I., Guru RA Al Hijrah Badrul Ulum)

Pembelajaran sistem luring dengan pola kunjungan ini mendapat perhatian khusus dan dukungan dari orang tua. Sebab, mereka merasa anak tetap aman belajar tanpa harus keluar rumah. Hal ini dibenarkan oleh Ruhaena \& Ambarwati (2015) yang berpendapat bahwa pengembangan minat dan bakat anak juga dapat dilakukan di rumah, bahkan rumah dipandang menjadi tempat "aman dan nyaman" bagi anak. Ini menunjukkan andil pendidikan di rumah memberi pengaruh positif bagi proses pembelajaran anak (Widodo \& Ruhaena, 2018).

Pola pembelajaran kunjungan sejatinya mirip dengan homeschooling (Awofala, 2020). Namun, homeschooling merupakan kebijakan tersendiri untuk memastikan hak belajar anak diperoleh (Purnamasari, 2017). Berbeda halnya dengan pola belajar kunjungan atas penerapan kebijakan social distancing di tengah situasi pandemi. Atas dasar kurang efektifnya belajar via WAG, "mau tidak mau" pihak TK berupaya agar anak tetap belajar dan tetap merasa aman dengan dikunjungi ke rumahnya.

Meskipun begitu, diakui pembelajaran sistem luring (kunjungan ke rumah) ini memiliki kelemahan, di antaranya penyediaan kudapan dan minuman oleh wali siswa, serta sarana pembelajaran yang tergolong berat dan susah dibawa bolak-balik dari rumah wali siswa yang satu ke rumah lainnya. Hal ini sebagaimana diungkapkan oleh Siti Molek menjelaskan:

"Belajar dengan mengunjungi rumah masing-masing wali murid sangat mengasyikkan, sebab kita dapat kembali bersilaturahmi dengan murid dan juga sekaligus orangtuanya walaupun harus pakai masker dan cuci tangan sebelum tegur sapa Bu, namanya juga perlindungan dan social distancing. Tapi, kendalanya di sana media yang besar-besar seperti balok dan lego-lego lainnya susah dibawa bolak-balik, dan kita juga segan kalau ke rumah murid, orangtuanya selalu menghidangkan makanan. Jadi, para guru menyampaikan kepada pimpinan atas masalah ini, mudah-mudahan diadakan rapat lagi, supaya dapat solusi yang lebih menguntungkan seluruh pihak." (Hasil Wawancara dengan Siti Molek, S.Pd.I., Guru RA Al Hijrah Badrul Ulum)

Kutipan wawancara di atas mengkonfirmasi beberapa kelemahan praktik pembelajaran kunjungan. Begitupun, pola ini dapat dijadikan sebagai alternatif untuk memastikan tetap berlangsungnya proses pendidikan bagi anak pra sekolah (usia dini). Hal senada dibenarkan oleh Wekke \& Saleh (2020) bahwa pembelajaran di masa pandemi tidak hanya metode daring (online) saja, kunjungan belajar pun dapat dijadikan alternatif pendidikan dengan mematuhi aturan social distancing. 
Dengan demikian, dipahami bahwa kunjungan belajar merupakan salah satu pola pembelajaran yang dapat diterapkan pada masa pandemi covid-19. Lebih lanjut, hal ini harus diikuti dengan mematuhi segala aturan tentang social distancing, untuk memastikan keamanan dan kenyamanan belajar anak dari gangguan virus corona dan telah berlangsung mulai awal hingga pertengahan bulan Juli.

\section{Pola Pembelajaran Bergilir}

Pola pembelajaran bergilir merupakan salah satu alternatif pembelajaran yang banyak diterapkan oleh lembaga pendidikan di era covid-19. Hal ini dianggap sebagai manifestasi tetap berlangsungnya pendidikan dengan social distancing. Pemaknaan social distancing dianggap menjadi pengaruh utama internal lembaga pendidikan menerapkan proses pembelajaran tersebut.

Sebagaimana yang diterapkan oleh enam TK/RA di Kutacane Aceh Tenggara. Mulanya, proses pembelajaran diawal masa pandemi berlangsung sejak Mei hingga Juli via WAG, selanjutnya Juli awal hingga pertengahan dengan sistem kunjungan belajar, tidak bertahan lama akhirnya pihak pimpinan TK/RA menetapkan pola pembelajaran bergilir di RA/TK tersebut. Hal ini selaras dengan yang diungkapkan Ely Nora berikut ini:

"Kalau belajar kunjungan ke rumah wali murid, media yang besar-besar seperti balok dan lego-lego lainnya kan susah dibawa bolak-balik. Akhirnya, sekolah memutuskan untuk belajar di sekolah dengan per shift. Dalam 1 kelas itu ada 2 shift dengan jumlah anak kira-kira 4 atau 5 orang selebihnya masuk di jam kedua. Dan selama belajar kita pakai protokol kesehatan, anak-anak diwajibkan memakai masker dan wajib cuci tangan, sebelum masuk juga kita check anak sebelum masuk sekolah, kita juga kasih pembatas atau jarak anak-anak saat berbaris ketika shalat Dhuha dan tahfidz, agar mematuhi peraturan social distancing Bu." (Hasil Wawancara dengan Bu Ely Nora, S.Pd.I., Guru RA Al Hasanah)

Kutipan wawancara di atas mengkonfirmasi bahwa peralihan pembelajaran menjadi pola bergilir (shift-shiftan) merupakan kesepakatan bersama pihak TK atas perubahan kondisi sesuai anjuran social distancing. Berikut ditampilkan gambar anak belajar dalam shift pertama yang berjumlah 5 anak.
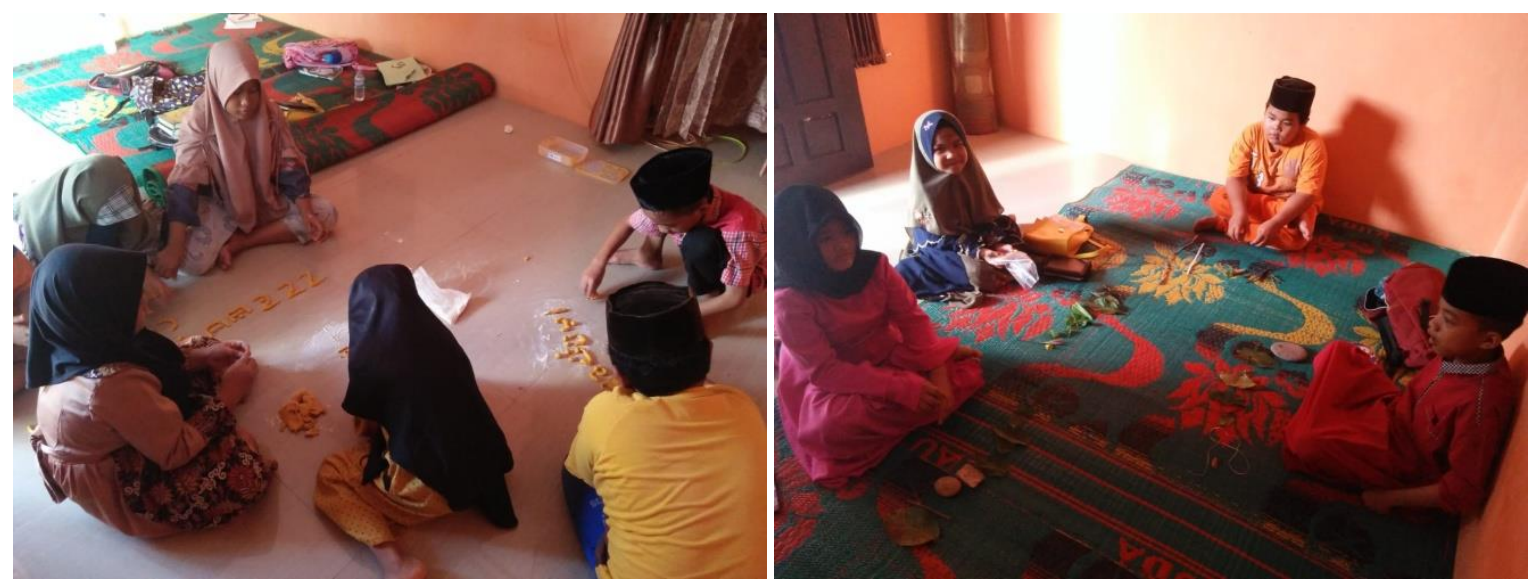

Gambar 1. Kegiatan Belajar Shift Pertama dan Shift Kedua Kelas Zamzami TK Balita Quran (Dokumentasi: Novita 25 Agustus 2020)

Berkaitan dengan gambar di atas, dipahami bahwa gambar (a) bagian kiri, merupakan tampilan gambar pembelajaran shift pertama (Jumlah Siswa hanya 5 orang atau setengah dari kelas biasanya). Sedangkan (b) bagian kanan, merupakan tampilan gambar pembelajaran shift kedua (Jumlah siswa hanya 4 orang atau setengah dari kelas biasanya). Adapun shift pertama dan shift kedua, belajar dengan waktu yang berbeda, yakni shift $1=08.00-09.30 \mathrm{WIB}$; shift $2=$ 10.00-11.30 WIB.

Hal ini senada dengan penjelasan dari Novita berikut ini: 
“...masuk setiap hari dengan cara bergantian atau per shift, 5 anak masuk jam 08:00 sampai 9.30 dan 4 anak lagi masuk jam 10.00 sampai 11:30. Pembelajaran seperti ini kami rasa cukup aman, siswa tetap $i k u t$ protokol kesehatan, benda-benda dan mainan tetap berada di TK, dan para guru merasa atmosfer mengajar kembali di ruang kelas TK. Intinya, tetap patuh juga sama panduan belajar social distancing Bu." (Hasil Wawancara dengan Novita Wulansari, S.Pd. Guru TK Balita Quran)

Peralihan pengajaran yang dilakukan oleh pihak sekolah (RA/TK) sejatinya merupakan kebijakan internal dalam memandang perubahan-perubahan kondisi pembelajaran selama pandemi covid-19. Hal ini juga didasari dari cara pandang pihak TK/RA terhadap peraturan social distancing. Dengan demikian, pihak sekolah mengedepankan kemaslahatan bersama, dengan prinsip siswa tetap belajar, guru tetap harus mengajar, dan keduanya tetap mematuhi aturan protokol kesehatan (social distancing) selama masa pandemi covid-19.

\section{Platfrom Pembelajaran Social Distancing pada PAUD di Era New Normal Pembelajaran}

Pembelajaran merupakan inti dari proses pendidikan. Di dalamnya terdapat interaksi dan komunikasi yang menghubungkan emosional, aspek sosial, dan motif belajar antara guru dan siswa. Untuk itu, pembelajaran tetap menjadi modal utama yang diprioritaskan terus terlaksana meskipun situasi pandemi covid-19.

Senada dengan di atas, Hewi \& Asnawati (2020) menyebutkan bahwa anak membutuhkan proses belajar dalam situasi darurat, termasuk era covid-19 untuk mampu tumbuh dan berkembang dengan berpikir logis. Lebih lanjut, Wulandari \& Purwanta (2020) menambahkan, pembelajaran daring (online) tergolong baru bagi kalangan satuan pendidikan jenjang TK/RA sederajat. Hal ini dilakukan sebagai upaya memastikan proses pembelajaran tetap berlangsung semasa pandemi covid-19.

Pelaksanaan pembelajaran dengan memerhatikan aspek social distancing di era covid19 menuju new normal menghadirkan perasaan "was-was" bagi pendidik anak usia dini. Sebagaimana diungkapkan Jumrah ketika diwawancarai berikut ini:

"Ada perbedaan ketika mengajar saat pendemi ini perasaan "was-was" ada ketika ada anak yang baru keluar kota lalu masuk ke sekolah. Tapi, pihak sekolah menyuruh anak-anak yang baru keluar kota harus isolasi mandiri dulu di rumah baru boleh ke sekolah, Kalau dari segi pelaksanaan belajar, waktunya kurang cukup untuk belajar karena setiap shift hanya belajar 1 jam setengah (1 jam 30 menit) jadi perkembangan anak kurang tercapai seperti yang diharapkan, tapi mau gimana lagi Bu, sudah syukurlah bisa tetap belajar dengan anak-anak walau pakai masker, cuci tangan, dan berjarak (social distancing)." (Hasil Wawancara dengan Jumrah, S.Pd.I., Guru RA Al Hijrah Badrul Ulum)

Kebutuhan anak akan belajar tentu menjadi alasan utama tetap dilaksanakannya pembelajaran (Hutami \& Nugraheni, 2020). Hal ini pula yang mengundang sejumlah platform pembelajaran dikembangkan semasa covid-19 (Gunawan, et.al., 2020:61-70). Seperti halnya yang dilaksanakan oleh keenam RA/TK di Kabupaten Aceh Tenggara, yang sejak Mei hingga Agustus telah 3 (tiga) kali mengganti sistem pembelajaran, mulai dari via WhatsApp Group (WAG), pola belajar kunjungan, dan kini menerapkan pembelajaran bergilir (shift-shiftan).

Berikut ditampilkan kegiatan pembelajaran yang dilaksanakan oleh Pihak RA Darul Falah: 


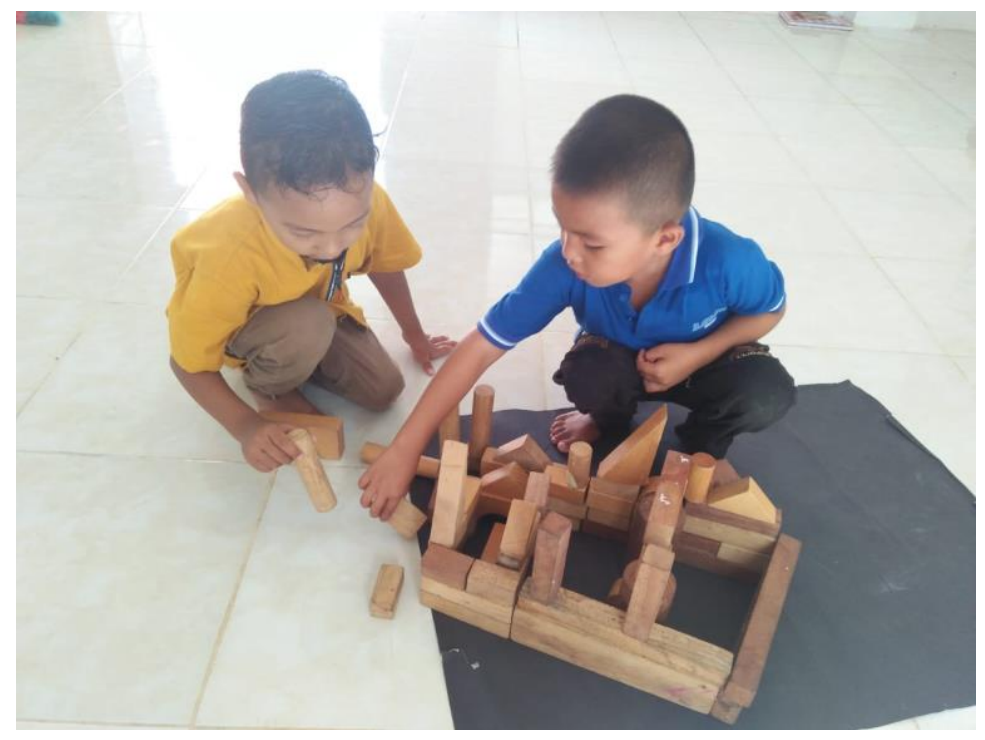

Gambar 2. Kegiatan Pembelajaran di kelas Quba' RA Darul Falah (Dokumentasi: Jumaiyah, 25 Agustus 2020, pukul 10.15 WIB)

Berkaitan dengan gambar di atas dan kesepakatan belajar sistem bergilir didasari pula atas penetapan zona merah dan hijau atas penyebaran virus corona (covid-19) yang berpengaruh terhadap kesiapan pembelajaran yang diterapkan oleh pihak lembaga pendidikan. Seperti halnya TK/RA di Kabupaten Aceh Tenggara, pelaksanaan pembelajaran tatap muka dengan sistem bergilir dilaksanakan atas dasar lingkungan (daerah) yang tergolong aman. Hal ini selaras dengan pernyataan Juli ketika diwawancarai berikut ini:

"Karena Kutacane masih lingkungan aman jadi kita tetap belajar seperti biasa hanya aja waktunya dikurangin. Jumlah muridnya pun kita bagi jadi dua kali shift. Pembagiannya kita sesuaikan absen siswa dengan memerhatikan aspek gender. Supaya, pembelajaran tetap heterogen di kelas dan sekolah dianggap tetap patuh aturan social distancing era covid-19." (Hasil Wawancara dengan Juli Sartika, S.Pd., Guru RA Al Kamal)

Kutipan wawancara di atas mengonfirmasi bahwa keadaan daerah kutacane yang masih tergolong aman menjadi alasan utama pihak TK/RA melaksanakan pembelajaran bergilir dengan tatap muka. Adapun kegiatan pembelajaran tetap dilaksanakan seperti masa normal, hanya saja pengurangan waktu dan jumlah siswa menjadi bentuk perubahan dalam aspek pembelajaran. Dengan demikian, pembelajaran di 6 (enam) RA/TK Kabupaten Aceh Tenggara yakni TK Balita Quran, RA Al Hasanah, RA Ali Mahfudz, RA Darul Falah, RA Al Kamal, dan RA Al Hijrah Badrul Ulum sejak Mei hingga Agustus 2020 tetap dilaksanakan, mulai dari belajar daring (via WhatsApp Group) dan luring (pola belajar kunjungan \& sistem bergilir).

\section{Penugasan}

Penugasan sejatinya diperbolehkan dalam dunia pendidikan (Trinova, 2012). Sebab, tugas tidak selamanya tentang membebani anak, melainkan mengoptimalkan waktu belajar dan penyelarasan belajar anak di rumah dan di sekolah (Ramli, 2015). Begitupun, butuh penyesuaian penugasan yang diberikan oleh guru terhadap anak, sehingga tidak mengganggu perkembangan anak (Amini, 2015).

Berkaitan dengan tugas, terdapat pula lembaga pendidikan yang tidak memberi PR pada siswa. Hal ini didasari pada pandangan beberapa wali siswa bahwa PR membebani anak di rumah, bahkan menyita waktu anak untuk kumpul dan berinteraksi dengan keluarga di rumah (Rohmawati, 2012).

Menyikapi perihal penugasan atau pekerjaan rumah (PR) bagi anak, pihak guru di keenam RA/TK tersebut tidak memberikan tugas rumah bagi anak. Hal ini mengacu pada 
kurikulum yang diterapkan RA/TK. Sebagaimana yang disampaikan Novita ketika diwawancarai berikut ini:

"Kalau untuk TK Balita Quran sih, program kita tidak ada PR (Pekerjaan Rumah) atau tugas untuk anak-anak. Karena PR (pekerjaan rumah) udah dihapus dari kurikulum sekolah. Kita hanya memastikan anak-anak muraja'ah hafalan dibimbing oleh orang tua dan memastikan anak di sekolah dengan mengikuti aturan social distancing dan memberikan pelajaran lewat bermain dengan metode sentra." (Hasil Wawancara dengan Novita Wulansari, S.Pd., Guru TK Balita Quran)

Senada dengan di atas, Jumaida menuturkan bahwa:

"untuk PR, sekolah tidak ada memberi penugasan lagi. Karena, kurikulum di sekolah tidak ingin memberi beban kepada anak-anak Bu. Malahan kami hanya meminta siswa menunjukkan hasil kreasinya di rumah untuk dibawa atau video semasa daring (online) ke sekolah tanpa paksaan. Itupun sengaja dibuat sebagai motivasi belajar anak aja Bu." (Hasil Wawancara dengan Jumaida Fitriani, S.Pd.I., Guru RA Ali Mahfudz)

Berdasarkan kutipan wawancara di atas, dipahami bahwa RA/TK tidak memberikan tugas atau PR bagi siswa. melainkan memastikan anak tetap murajaah hafalan dan memberi alternatif pembelajaran lainnya, sebab PR telah dihapus dalam kurikulum sekolah.

\section{Penilaian}

Penilaian merupakan aspek penting dalam proses pembelajaran (Rahmawati \& Gajewski, 2018). Tahap penilaian akan menampilkan tolak ukur keberhasilan pembelajaran (Abdullah, 2015). Kemampuan siswa dalam aspek kognitif, afektif dan psikomotorik diukur dan dinilai dalam tahap ini. Untuk itu, tahapan penilaian penting adanya dalam proses pembelajaran.

Adapun bentuk penilaian yang diterapkan pihak RA/TK Kabupaten Aceh Tenggara mengacu pada kemampuan, kemandirian dan karakter yang ditampilkan anak dalam kesehariannya. Hal ini selaras dengan pernyataan Novita ketika diwawancarai berikut ini:

"Bentuk penilaian untuk anak TK Balita Qur'an ini dik ditinjau dengan melihat kemampuan anak dalam mengenal huruf dan angka, hafalan dan kemandirian serta karakter anak. Nanti ummi guru (sebutan guru di TK Balita Quran) mencatat perkembangannya di buku perkembangan yang sudah disediakan di sekolah contoh penilaian: (1) Rizki sudah bisa mengenal huruf A sampai Z, (2) Rizki sudah hafal surat an-Naba' dari ayat 1- 35, (3) Rizki sudah bisa makan sendiri, dan (4) Rizki sudah bisa membereskan mainan ke dalam kotak dengan rapi. Sejatinya, ini sama kok Bu dengan penilaian ketika sebelum covid19, bedanya hanya kita harus memastikan anak dan guru-guru di sekolah ikut aturan social distancing." (Hasil Wawancara dengan Novita Wulansari, S.Pd., Guru TK Balita Quran) rumah:

Berikut ditampilkan gambar siswa yang telah mampu menyusun permainan seperti

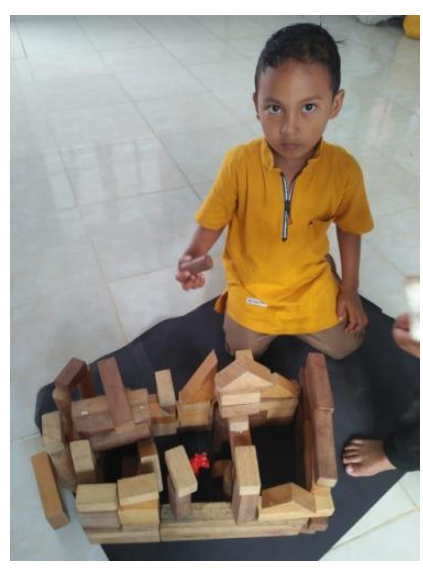

Gambar 3. Hasil Rumah yang telah Berhasil Disusun Siswa.

(Dokumentasi: Jumaiyah, S.Pd.I., 25 Agustus 2020) 
Berkaitan dengan gambar di atas menunjukkan antusias siswa dalam belajar di tengah pandemi, hal ini dipraktikkan untuk melatih kesabaran anak dalam menyusun bentuk rumah dan melatih kemandirian belajar anak. Lebih lanjut, hasil elaborasi dokumentasi dan wawancara di atas dapat dipahami bahwa aspek penilaian di enam RA/TK Aceh Tenggara meliputi kemampuan anak dalam mengenal huruf dan angka. Selanjutnya karena RA/TK ini berlokasi di daerah serambi Makkah, maka hafalan Quran dan doa pendek menjadi salah satu aspek penilaian. Di samping itu, untuk mengamati perkembangan anak, maka dinilai pula kemandirian dan karakter anak.

\section{SIMPULAN}

Pendidikan AUD menjadi aspek yang patut diperhatikan di masa penerapan social discancing dan menuju era new normal. Berdasarkan penelitian pada 6 RA/TK di Aceh Tenggara dengan partisipan 8 guru RA/TK tersebut, ditemukan bahwa (1) guru memandang bahwa social distancing adalah pembatasan jarak sosial sementara karena pandemi, untuk itu pendidikan pada AUD di RA/TK Kab. Aceh Tenggara mengalami 3 kali transisi pola, mulai dari via WhatsApp Group (WAG), belajar kunjungan dan sistem bergilir; dan (2) platform social distancing pada PAUD di era new normal meliputi aspek pembelajaran, penugasan dan penilaian.

\section{UCAPAN TERIMA KASIH}

Peneliti mengucapkan terimakasih banyak kepada para partisipan yang telah bersedia memberi informasi terkait persepsi guru tentang social distancing pada pembelajaran AUD era new normal. Adapun nama-nama para partisipan tersebut yakni, Ibu Novita Wulansari, S.Pd. (dari TK Balita Qur'an), Ibu Jumrah, S.Pd.I., Ibu Siti Molek, S.Pd.I., dan Ibu Darma Taksiah, S.Pd.I. (dari RA Al Hijrah Badrul Ulum), Ibu Ely Nora, S.Pd.I. (dari RA Al Hasanah), Ibu Jumaida Fitriani, S.Pd.I. (dari RA Ali Mahfudz), Ibu Jumaiyah, S.Pd.I. (dari RA Darul Falah) dan Ibu Juli Sartika, S.Pd. (dari RA Al Kamal).

\section{DAFTAR PUSTAKA}

Abdullah, Ramli. (2015). “Urgensi Penilaian Hasil Belajar Berbasis Kelas Mata Pelajaran IPS di Madrasah Tsanawiyah" Lantanida Journal, 3(2). http://dx.doi.org/10.22373/lj.v3i2.1657.

Abidah, Azmil, et.al. (2020). "The Impact of Covid-19 to Indonesian Education and Its Relation to the Philosophy of 'Merdeka Belajar'" SIPOSE: Studies in Philosophy of Science and Education, 1(1): 38-49. https://doi.org/10.46627/sipose.v1i1.9.

Amini, Mukti. (2015). "Profil Keterlibatan Orang Tua dalam Pendidikan Anak Usia TK" VISI: Jurnal Ilmiah Pendidik dan Tenaga Kependidikan Pendidikan Non Formal, 10(1). https://doi.org/10.21009/JIV.1001.2.

Arizona, Kurniawan, et.al. (2020). "Pembelajaran Online Berbasis Proyek Salah Satu Solusi Kegiatan Belajar Mengajar di Tengah Pandemi Covid-19" Jurnal Ilmiah Profesi Pendidikan, 5(1). http://www.jipp.unram.ac.id/index.php/jipp/article/view/111.

Asfiati \& Nur Imam Mahdi. (2020). “Merdeka Belajar bagi Anak Berkebutuhan Khusus di SLB Kumala Indah Padangsidimpuan" Kindergarten: Journal of Islamic Early Childhood Education, 3(1). http:/ / dx.doi.org/10.24014/kjiece.v3i1.9620.

Astini, Ni Komang Suni. (2020). “Tantangan dan Peluang Pemanfaatan Teknologi Informasi dalam Pembelajaran Online Masa Covid-19" Cetta: Jurnal Ilmu Pendidikan, 3(2): 241-255. https://doi.org/10.33449/jpmr.v5i2.11410.

Awofala, Adeneye O. A. (2020). "Covid-19 Pandemic in Nigeria and Attitudes Towards Mathematics Homeschooling Among Pre-Tertiary Students" Nigerian Online Journal of Educational Sciences and Technology, http://jepa.unilag.edu.ng/index.php/nojest/article/view/915. 
Braun, V. \& Clarke, V. (2012). Thematic analysis. In H. Cooper, P. M. Camic, D. L. Long, A. T. Panter, D. Rindskopf, \& K. J. Sher (Eds), APA handbook of research methods in psychology, Vol. 2: Research designs: Quantitative, qualitative, neuropsychological, and biological (pp. 5771). Washington, DC: American Psychological Association.

Cahyati, Nika \& Rita Kusumah. (2020). "Peran Orang Tua dalam Menerapkan Pembelajaran di Rumah Saat Pandemi Covid 19" Jurnal Golden Age, 4(1). http://www.ejournal.hamzanwadi.ac.id/index.php/jga/article/view/2203.

Courtemanche, Charles, et.al. (2020). "Strong Social Distancing Measures in the United States Reduced the Covid-19 Growth Rate" Health Affairs, 39(7). https:// doi.org/10.1377/hlthaff.2020.00608.

Creswell, John W. (2009). Research Design Qualitative, Quantitative, and Mixed Methods Approaches. California: SAGE Publications, Inc.

Crul, Maurice, et.al. (2017). "No Lost Generation? Education for Refugee Children". http://hmm.igeucla.org/wp-content/uploads/2017/01/Education-for-refugeechildren-Crul-et-al-DRAFT.pdf.

Dewi, Wahyu Aji Fatma. (2020). “Dampak Covid-19 Terhadap Implementasi Pembelajaran Daring di Sekolah Dasar" Edukatif: Jurnal Ilmu Pendidikan, 2(1): 55-61. https:// core.ac.uk/reader/322536540.

Ellanur, Carona. (2017). "Pemanfaatan Aplikasi WhatsApp sebagai Sarana Diskusi antara Pengawas dan Guru Pendidikan Agama Islam" Jurnal As-Salam, 1(2): 1-14. http://www.jurnal-assalam.org/index.php/JAS/article/view/80.

Firman. (2020). "Dampak Covid-19 Terhadap Pembelajaran di Perguruan Tinggi" BIOMA: Jurnal Biologi dan Pembelajarannya, 2(1). https://ojs.unsulbar.ac.id/index.php/bioma/article/view/743.

Gunawan, et.al. (2020). "Variations of Models and Learning Platforms for Prospective Teachers During the Covid-19 Pandemic Period" Indonesian Journal of Teacher Education, 1(2): 6170. https://journal.publication-center.com/index.php/ijte/article/view/95.

Hanoatubun, Silpa. (2020). "Dampak Covid-19 Terhadap Perekonomian Indonesia" EduPsyCouns: Journal of Education, Psychology and Counseling, 2(1): 146-153. https://ummaspul.e-journal.id/Edupsycouns/article/view/423.

Hennick, Monique M. (2014). Focus Group Discussions. New York: Oxford University Press.

Herdiana, Dian. (2020). “Social Distancing: Indonesian Policy Response to The Corona Virus Disease 2019 (Covid-19)" Jurnal Ilmu Administrasi, 17(1). https:// doi.org/10.31113/jia.v17i1.555.

Hewi, La \& Linda Asnawati. (2020). "Strategi Pendidik Anak Usia Dini Era Covid-19 dalam Menumbuhkan Kemampuan Berpikir Logis" Jurnal Obsesi, 5(1). https:// doi.org/10.31004/obsesi.v5i1.530.

Hutami, Meyda Setyana \& Aninditya Sri Nugraheni. (2020). “Metode Pembelajaran Melalui WhatsApp Group Sebagai Antisipasi Penyebaran Covid-19 pada AUD di TK ABA Kleco Kotagede" PAUDIA: Jurnal Penelitian dalam Bidang Pendidikan Anak Usia Dini, 9(1). http://journal.upgris.ac.id/index.php/paudia/article/view/6107.

Ikhsan, et.al. (2020). “Upaya Perlindungan Anak dalam Peradilan Pidana di Era Pemberlakuan 'New Normal' Selama Pandemi Covid-19 di Indonesia" Jurnal Ilmu Hukum, 9(2). http://dx.doi.org/10.30652/jih.v9i2.7933.

Indrawati, Budi. (2020). “Tantangan dan Peluang Pendidikan Tinggi dalam Masa dan Pasca Pandemi Covid-19" Jurnal Kajian Ilmiah, 1(1): 39-48. https:// doi.org/10.37092/ej.v3i1.224.

Indrayana, Boy \& Ali Sadikin. (2020). “Penerapan E-Learning di Era Revolusi Industri 4.0 untuk Menekan Penyebaran Covid-19" Indonesian Journal of Sport Science and Coaching, 2(1): 46-55. https://doi.org/10.22437/bio.v6i2.9759. 
DOI: 10.31004/obsesi.v5i2.756

Juwita, Dewi Ratna. (2020). “Makna Posyandu Sebagai Sarana Pembelajaran Non Formal di Masa Pandemic Covid 19" Meretas: Jurnal Ilmu Pendidikan, 7(1). http://jurnal.upgriplk.ac.id/index.php/meretas/article/view/159.

Kurniawan, Yosep. (2020). "Implementasi Merdeka Belajar Berdasarkan Ajaran Tamansiswa dalam Pembelajaran Bahasa Inggris Lembaga Kursus Kelas Anak-anak" Seminar $\begin{array}{lllll}\text { Nasional } & \text { Pendidikan } & 7 & \text { Maret } & \end{array}$ http://jurnal.ustjogja.ac.id/index.php/semnas2020/article/view/7375.

Latip, Abdul. (2020). “Peran Literasi Teknologi Informasi dan Komunikasi pada Pembelajaran Jarak Jauh di Masa Pandemi Covid-19" EduTeach: Jurnal Edukasi dan Teknologi Pembelajaran, 1(2), 2020.

Leavy, Patricia. (2017). Research Design Quantitative, Qualitative, Mixed Methods, Arts-Based, and Community-Based Participatory Research Approaches. New York: The Guilford Press

Marbun, Purim. (2020). "Disain Pembelajaran Online pada Era dan Pasca Covid-19" Computer Science Research and Its Development Journal, 12(2): 129-142. http://dx.doi.org/10.22303/csrid.12.2.2020.129-142.

Mauly, Yuka Kholyssa. (2020). “Metode Pembelajaran Daring Menggunakan Aplikasi Online pada Masa Pandemi Covid-19 di SMPIT Az-Zahra Sragen Tahun Pembelajaran 2019/2020" Skripsi. Surakarta: Universitas Muhammadiyah Surakarta. http://eprints.ums.ac.id/84044/.

Megawanti, Priarti, et.al. (2020). “Persepsi Peserta Didik Terhadap PJJ pada Masa Pandemi Covid 19" Faktor Jurnal Ilmiah Kependidikan, 7(2). https://journal.lppmunindra.ac.id/index.php/Faktor/article/view/6411.

Mungkasa, Oswar. (2020). “Bekerja dari Rumah (Working From Home/WFH): Menuju Tatanan Baru Era Pandemi Covid 19" The Indonesian Journal of Development Planning, 4(2): 126-150. https://doi.org/10.36574/jpp.v4i2.119.

Mushlih, Miftahul, et.al. (2020). “Pendampingan Sekolah Dasar Neger 4 Kupang, Jabon dalam Menghadapi New Normal" Humanism: Jurnal Pengabdian Masyarakat, 1(2). http://dx.doi.org/10.30651/hm.v1i2.5565.

Mustaghfiroh, Siti. (2020). “Konsep 'Merdeka Belajar' Perspektif Aliran Progresivisme John Dewey" Jurnal Studi Guru dan Pembelajaran, 3(1): 141-147. https://doi.org/10.30605/jsgp.3.1.2020.248.

Naserly, Mursyid Kasmir. (2020). "Implementasi Zoom, Google Classroom, dan WhatsApp Group dalam Mendukung Pembelajaran Daring (Online) pada Mata Kuliah Bahasa Inggris Lanjut (Studi Kasus pada 2 Kelas Semester 2, Jurusan Administrasi Bisnis, Fakultas Ekonomi dan Bisnis, Universitas Bina Sa)" Aksara Public, 4(2): 155-165. http://aksarapublic.com/index.php/home/article/view/417.

Nurhalimah, Neneng. (2020). “Upaya Bela Negara Melalui Social Distancing dan Lockdown untuk Mengatasi Wabah Covid-19 (Efforts to Defend the Country Through Social Distancing and Lockdown to Overcome the Covid-19 Plague)" SSRN. https://dx.doi.org/10.2139/ssrn.3576405.

Perdana, Novan Satria. (2015). "Faktor-faktor yang Berpengaruh Terhadap Aksesbilitas Memperoleh Pendidikan untuk Anak-anak di Indonesia" Jurnal Pendidikan dan Kebudayaan, 21(3): 279-297. https:/ / core.ac.uk/download/pdf/227142787.pdf.

Permatasari, Andalusia Neneng, et.al. (2020). "Keintiman Komunikasi Keluarga saat Social Distancing Pandemi Covid-19” Jurnal Obsesi, 5(1). https://doi.org/10.31004/obsesi.v5i1.577.

Pramana, Cipta. (2020). "Pembelajaran Pendidikan Anak Usia Dini (PAUD) di Masa Pandemi Covid-19" Indonesian Journal of Early Childhood, 2(2). http:// dx.doi.org/10.35473/ijec.v2i2.557.

Purnamasari, Iin. (2017). "Homeschooling dalam Potret Politik Pendidikan: Studi Etnografi pada Pelaku Homeschooling di Yogyakarta" Journal of Nonformal Education, 3(1). https://doi.org/10.15294/jne.v3i1.8844. 
Rahmawati, Laili Etika \& Dawid Michal Gajewski. (2018). "Urgensi Penilaian dalam Pembelajaran BIPA" Publikasi Ilmiah. http://hdl.handle.net/11617/9904.

Rahmawati \& Evita Muslima Isnanda Putri. (2020). "Learning From Home dalam Perspektif Persepsi Mahasiswa Era Pandemi Covid-19" Prosiding Seminar Nasional Hardiknas, 1(1). http:// proceedings.ideaspublishing.co.id/index.php/hardiknas/article/view/3.

Ramli, M. (2015). "Hakikat Pendidik dan Peserta Didik" Tarbiyah Islamiyah: Jurnal Ilmiah Pendidikan Agama Islam, 5(1). https:/ / dx.doi.org/10.18592/jt\%20ipai.v5i1.1825.

Riadi, Selamat, et.al. (2020). "Perspsi Mahasiswa Prodi S1 Geografi Fisip ULM Terhadap Kuliah Online di Masa Pandemi Covid-19" Padaringan, 2(2). https://ppjp.ulm.ac.id/journals/index.php/padaringan/article/view/2151.

Rohayani, Farida. (2020). "Menjawab Problematika yang Dihadapi Anak Usia Dini di Masa Pandemi Covid-19" Qawwam, 14(1). https://doi.org/10.20414/qawwam.v14i1.2310.

Rohmadani, Adinda Icha. (2020). "Dampak Covid 19 Terhadap Cara Berpikir dalam Pembelajaran Daring: Studi Kasus di Yogyakarta" Edification Journal: Pendidikan Agama Islam, 3(1). https://doi.org/10.37092/ej.v3i1.224.

Rohmawati, Cicik. (2012). “Usaha Guru untuk Mengatasi Kenakalan Anak Kelas V SD Negeri Kliwonan 2 Masaran Sragen Tahun Pelajaran 2011/2012" Skripsi. Surakarta: Universitas Muhammadiyah Surakarta. http://eprints.ums.ac.id/21193/.

Ruhaena, Lisnawati \& Juni Ambarwati. (2015). “Pengembangan Minat dan Kemampuan Literasi Awal Anak Prasekolah di Rumah" Publikasi Ilmiah UMS, The $2^{\text {nd }}$ University Research Colloquium (URECOL) 2015. http:/ /hdl.handle.net/11617/6881.

Sabiq, Ahmad Fikri. (2020). "Persepsi Orang Tua Siswa tentang Kegiatan Belajar di Rumah sebagai Dampak Penyebaran Covid 19" CIVIC-CULTURE: Jurnal Ilmu Pendidikan PKn $\mathcal{E}$ Sosial Budaya, 4(1): 1-7. https://doi.org/10.31597/cc.v4i1.322.

Sadikin, Ali \& Afreni Hamidah. (2020). "Pembelajaran Daring di Tengah Wabah Covid-19" Biodik: Jurnal Ilmiah Pendidikan Biologi, 6(2): 214-224. https:/ / doi.org/10.22437/bio.v6i2.9759.

Sari, Diah Andika, et.al. (2020). “Kesiapan Ibu Bermain Bersama Anak Selama Pandemi Covid19, 'Di Rumah Saja'” Jurnal Obsesi, 5(1), 2020. https:// doi.org/10.31004/obsesi.v5i1.584.

Satrianingrum, Arifah Prima \& Iis Prasetyo. (2020). “Persepsi Guru Dampak Pandemi Covid19 Terhadap Pelaksanaan Pembelajaran Daring di PAUD" Jurnal Obsesi, 5(1). https:// doi.org/10.31004/obsesi.v5i1.574.

Seidman, I. 2006. Interviewing as qualitative research. A guide for researchers in education and the social sciences. New York and London: Teachers College, Columbia University. [Google Scholar]

Siagian, Tiodora Hadumaon. (2020). "Mencari Kelompok Berisiko Tinggi Terinfeksi Virus Corona dengan Discourse Network Analysis" Jurnal Kebijakan Kesehatan Indonesia, 9(2). https:// doi.org/10.22146/jkki.55475.

Sutrisno. (2020). “Increased Learning Activities and Outcomes Through Online Learning with Google Classroom in the Covid-19 Pandemic Period" Ideguru: Jurnal Karya Ilmiah Guru, $5(1)$. https://jurnaldikpora.jogjaprov.go.id/index.php/jurnalideguru/article/view/151.

Syarifudin, Albitar Septian. (2020). “Implementasi Pembelajaran Daring untuk Meningkatkan Mutu Pendidikan Sebagai Dampak Diterapkannya Social Distancing" Metalingua: Jurnal Pendidikan Bahasa dan Sastra Indonesia, 5(1). https:/ / doi.org/10.21107/metalingua.v5i1.7072.

Tabi'in, A. (2020). "Problematika Stay at Home pada Anak Usia Dini di Tengah Pandemi Covid 19" Jurnal Golden Age, 4(1). http://ejournal.hamzanwadi.ac.id/index.php/jga/article/view/2244.

Tarma \& Uswatun Hasanah. (2017). “Workshop Parental Control Berbasis Android untuk Mencegah Akses Konten Pornografi pada Anak Usia Sekolah Dasar di Desa Cililin 
DOI: 10.31004/obsesi.v5i2.756

Kecamatan Cililin Kabupaten Bandung Barat" Sarwahita: Jurnal Pengabdian kepada Masyarakat, 14(2). https:// doi.org/10.21009/sarwahita.142.09.

Trinova, Zulvia. (2012). "Hakikat Belajar dan Bermain Menyenangkan Bagi Peserta Didik" AlTa'lim Journal, 19(3). https:/ / doi.org/10.15548/jt.v19i3.55.

Ulinnuha, Masyari. (2013). "Melindungi Anak dari Konten Negatif Internet: Studi Terhadap Peramban Web Khusus Anak" Sawwa, 8(2). https://journal.walisongo.ac.id/index.php/sawwa/article/viewFile/661/599

Ulum, Muhammad Syahrul \& Jati Pamungkas. (2020). “Analisis Kritis Penerapan Metode Pembelajaran Berbasis Online di Madrasah Ibtidaiyah Masa Pandemi Covid 19 (Solusi Menyelamatkan Masa Depan Anak-anak Indonesia)" Mubtadi: Jurnal Pendidikan Ibtidaiyah, 2(1). http://dx.doi.org/10.19105/mubtadi.v2i1.3584.

Wekke, Ismail \& Ahmad Saleh. (2020). “Pembelajaran di Masa Pandemi: Tidak Hanya Metode Daring Saja" OSFpreprints. https://doi.org/10.31219/osf.io/njtku.

Wibowo, Fitroh Setyo Putro. (2020). "Persepsi Guru SD Muhammadiyah Terhadap Penggunaan Gawai dalam Pembelajaran di Kelas" Proceeding Universitas Muhammadiyah Surabaya. http://journal.umsurabaya.ac.id/index.php/Pro/article/view/4885.

Widodo, Mulyo Manggih \& Lisnawati Ruhaena. (2018). “Lingkungan Literasi di Rumah pada Anak Pra Sekolah" Indigenous: Jurnal Ilmiah Psikologi, 3(1). https://doi.org/10.23917/indigenous.v3i1.3059.

Wijoyo, Hadion \& Irjus Indrawan. (2020). “Model Pembelajaran Menyongsong New Era Normal pada Lembaga PAUD di RIAU" Jurnal Sekolah, 4(3). https://doi.org/10.24114/js.v4i3.18526.

Wulandari, Hesti \& Edi Purwanta. (2020). "Pencapaian Perkembangan Anak Usia Dini di Taman Kanak-Kanak Selama Pembelajaran Daring di Masa Pandemi Covid-19" Jurnal Obsesi, 5(1). https:/ / doi.org/10.31004/obsesi.v5i1.626,

Wulandari, Indra Murti. (2020). "Peran Guru Mengoptimalkan Unit Kesehatan Sekolah untuk Melakukan Pencegahan Covid-19" Edukatif: Jurnal Ilmu Pendidikan, 2(1). https://doi.org/10.31004/edukatif.v2i1.88.

Yensy, Nurul Astuty. (2020). "Efektivitas Pembelajaran Statistika Matematika Melalui Media WhatsApp Group Ditinjau dari Hasil Belajar Mahasiswa (Masa Pandemik Covid 19)" Raflesia: Jurnal Pendidikan Matematika, 5(2). https:/ / doi.org/10.33449/jpmr.v5i2.11410.

Yuniarti, Ratna \& Widya Hartati. (2020). "Persepsi Mahasiswa tentang Penerapan E-Learning pada Masa Darurat Covid-19" Apotema: Jurnal Program Studi Matematika, 6(2). https://doi.org/10.31597/ja.v6i2.377.

Yin, Robert K. (2009). Case Study Research: Design and Methods. California: SAGE Inc.

Zhafira, Nabila Hilmy, et.al. (2020). "Persepsi Mahasiswa Terhadap Perkuliahan Daring sebagai Sarana Pembelajaran" Jurnal Bisnis dan Kajian Strategi Manajemen, 4(1). https://doi.org/10.35308/jbkan.v4i1.1981. 